\title{
Self-Identity of Millennial Generation as Traveling and Tourism Lovers Case Study Concerning Demographic And Psychographic Map of Tourism Communication
}

\author{
Jenny Ratna Suminar, Ditha Prasanti, Moch. Armien Syifaa Sutarjo \\ Faculty of Communication Science Padjadjaran University
}

\begin{abstract}
The millennial generation is in the range of 23 to 38 years, which is now a productive and attractive workforce group. It is interesting to be studied where one of their characteristics is prioritizing Work-Life-Balance. It is a term where the generation prioritizes a balance between the world of work and personal life compared to previous generations. They tend to choose jobs that are more flexible in terms of conditions and working hours. So they can have more free time with friends, family, or to develop a hobby as it is stated in the results of research conducted by Ng Schweitzer and Lyons (2010). It is reinforced by the statement that the characteristics that describe the next millennial generation are that they would rather spend money to get certain experiences rather than save to add assets. Of course, millennials generally prefer to travel around Indonesia and the world rather than save for investment. This research aims to: 1) Determine millennial's motivation for traveling; 2). Know how traveling is favored by millennials. The research uses a qualitative method with a phenomenological tradition where the data are collected by conducting in-depth interviews. The results of this study provide information about the demographic and psychographic data of millennials, which can be necessary for traveling and tourism businesses to understand who is the target in a pleasant and profitable business.
\end{abstract}

Keywords: Millenial, Traveling and Tourism, Phenomenology

This is an open access article under the CC-BY-NC license.

\section{INTRODUCTION}

Who does not like traveling? The question becomes more interesting to be developed because it turns out that not everyone enjoys traveling. Another case, for the traveling and tourism lovers, the answers that arise about his traveling activities can be varied. The focus of the research conducted in this paper is about the self-identity of the millennial generation of traveling and tourism lovers in Indonesia. Millennials who are the target of the research are those aged 26-30 years old and domiciled in West Java.

At present, the millennial generation often becomes one of the objects of research in several relevant topics. One of them is Croitoru (2017), who describes the development of innovation and technology for the millennial generation. Throughout the world, society is experiencing rapid development. It can also achieve a sustainable competitive advantage so that it becomes a real need in a global context. It was done as an effort to attract new customers and maintain the existing ones. In the field of tourism, the fastest growing economic sector cannot stand alone without innovation 
Tourism and Sustainable Development Review Journal (TSDR), Vol. 1 (1), 25-32

Self-Identity of Millennial Generation as Traveling and Tourism Lovers Case Study Concerning

Demographic And Psychographic Map Of Tourism Communication

Jenny Ratna Suminar, Ditha Prasanti, Moch. Armien Syifaa Sutarjo

and technology. According to him, the tourism sector is the area with the most significant potential in Indonesia. Thus, in the context of increasing consumer needs, especially those in the millennial generation, innovation and technology are the key factors in the future development of the travel industry (Croitoru, 2017).

In this study, the researchers see the support of innovation and technology that can become a significant factor in millennial generation in the development of the economic and tourism sector in Indonesia. The latest data also shows that the millennial generation has a particular purpose in traveling. Rita, P; Brochado, A; \& Dimova, L (2019) reveal that millennial generation is one of the largest groups targeted by tourism companies. The paper also compares the motivation of millennial generations to travel from the United States and Britain. The study also uses a questionnaire to examine the motivation of American and British millennials ( $\mathrm{n}=322$ ). Data analysis includes the non-parametric Mann-Whitney $U$ test, the Kendall suitability coefficient, the least squares-squared algorithm model (ALSCAL), and ordinal regression. The results of the study also show that the millennial generation of America and Britain is quite homogeneous in their drive motivation and activity preferences. The most important motivating factors for both are 'to relax' and 'to run away from ordinary things.' The two countries also agree that the most interesting activity destinations are 'trying local food' and 'going for a walk.' The findings show that the US and UK samples are similar, and there is room for segmentation according to demographics (Rita, P., Brochado, A., \& Dimova, 2019)

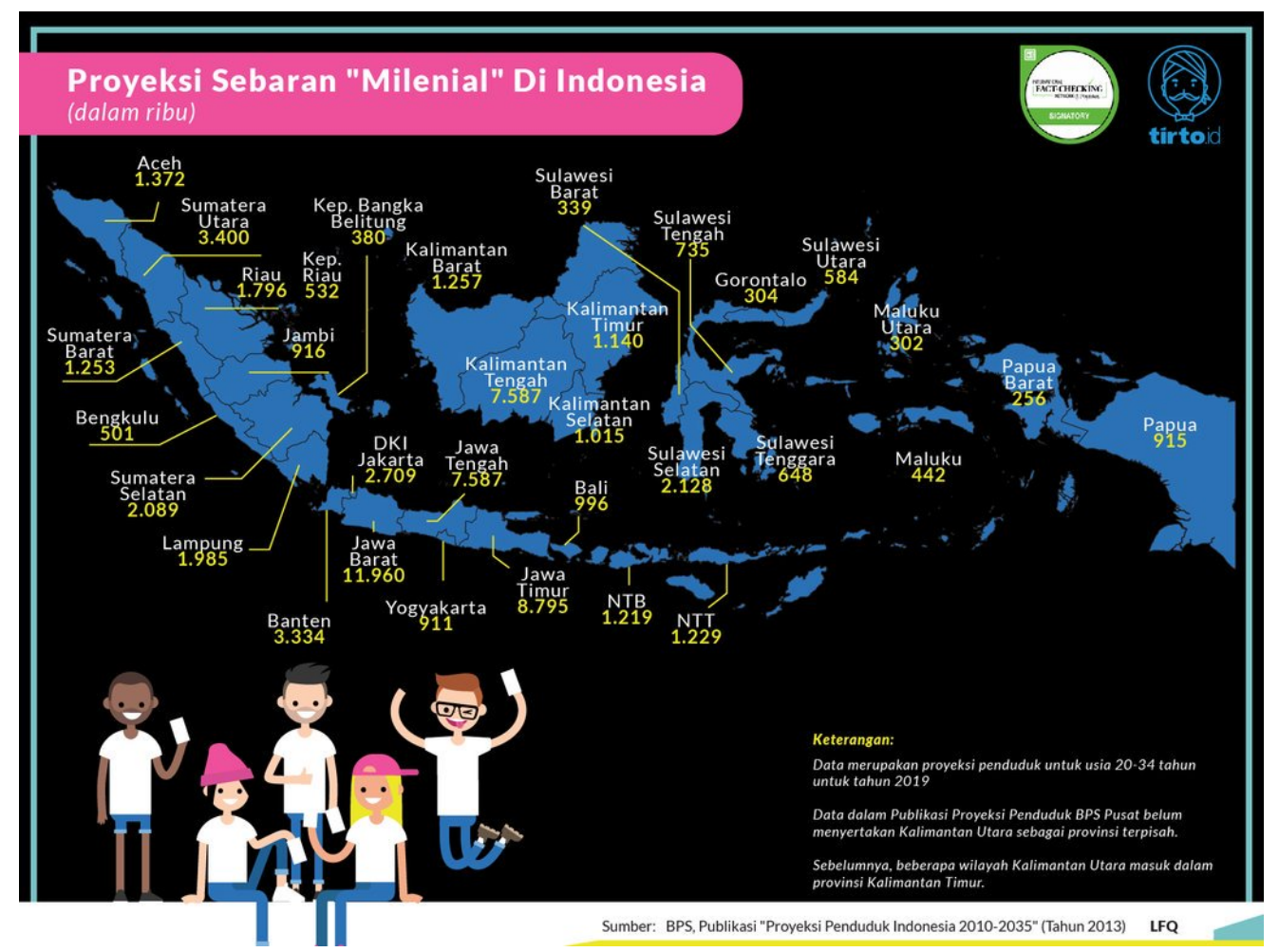

Figure 1. Data of Millenial Generation in Indonesia

(Source : Tirto.id, 2018) 
Tourism and Sustainable Development Review Journal (TSDR), Vol. 1 (1), 25-32

Self-Identity of Millennial Generation as Traveling and Tourism Lovers Case Study Concerning

Demographic And Psychographic Map Of Tourism Communication

Jenny Ratna Suminar, Ditha Prasanti, Moch. Armien Syifaa Sutarjo

Other data that make this research interesting and worth to be appointed are as illustrated in the picture above about the projection of millennial distribution in Indonesia. Noted that there are 11,960 millennials in West Java. The data is revealed by Garnesia (2018) in tirto.id. Based on BPS projections, the prediction of the dominant millennial distribution is in Java. The region contributes 53.95 percent of the total votes of millennial groups in Indonesia. This figure comes from West Java, which is inhabited by 18.77 percent of the millennial group, followed by East Java with 13.80 percent, and Central Java with 11.91 percent (Garnesia, 2018).

The numbers become important data in the sustainability of the tourism sector in Indonesia. Especially considering that the millennial generation dominates in West Java, the researchers are interested in expressing this research using a qualitative approach. Therefore, the self-identity of the millennial generation of traveling and tourism lovers in West Java will be a new finding that will add the data on the demographic and psychographic maps of tourism communication in Indonesia, especially for millennials.

\section{LITERATURE REVIEW}

The study of the millennial generation is growing. Other studies that support the researchers' topic are those expressed by Madara, Maheswari, and Selvan (2018). They also reveal about the millennial generation, which has a foundation in the pre-digital world but has grown with technology. Most millennials who grow up in the era of digital technology have more choices than the previous generations. They are known for many positive characteristics because they are the most technologically advanced generation. Millennials think about careers a little differently, which has a consistent path, speed, and pause. In the article, Madara et al. describe the way millennials shape the world. They argue that there are three critical elements in the concept of lifelong learning for the millennial generation, including curiosity, empathy, and passion for what is done. These skills will help millennials to stay in their jobs longer and build better career prospects (Madara, $\mathrm{S}$. R., Maheshwari, P., \& Selvan, 2018).

Another thing that researchers consider in choosing the millennial generation as the object of the research is the data revealed by Ng Schweitzer and Lyons (2010). The age of the millennial generation is in the range of 26 to 30 years, which is now a productive workforce group. It is interesting to study, one of their characteristics, which is to prioritize Work-Life-Balance. This millennial generation prioritizes a balance between the world of work and personal life compared to previous generations. They tend to choose jobs that are more flexible in terms of conditions and working hours so that they can have more free time with friends, family, or to develop a hobby, as the results of the research they do (Ng, ES, Schweitzer, L., \& Lyons, 2010). It is Strengthened by the statement that the next characteristic that describes the millennial generation is that they would rather spend money to get a particular experience rather than saving to add assets. Of course, millennials generally prefer to travel around Indonesia and the world rather than saving for investment.

\section{RESEARCH METHOD}

In this study, the researchers use a qualitative approach with a phenomenology method. As expressed by Creswell (2012) regarding its characteristics, phenomenology is a method that 
presents data in-depth regarding the meaning of the conscious experience of the key informants in the study (Creswell, 2012). Departing from this feature is interesting to study the millennial generation in terms of traveling and tourism. It should also be stated that this study aims to reveal: 1). The motivation of millennials to go traveling; 2) How millennial travels.

After that, data is also collected by using literature studies, and in-depth interviews with key informants who have the following criteria: including the age of millennial generation; the worker; a hobby of traveling and travel; able to articulate his experiences in terms of traveling.

\section{FINDINGS AND DISCUSSION}

The findings of this study are interesting to be described since they reveal the results that complement the data from a combination of some previous literature references on traveling for millennials. The researchers managed to find eight informants according to the research criteria, whose initials below represent the location of West Java:

\begin{tabular}{|l|l|l|l|l|l|l|}
\hline No & $\begin{array}{l}\text { Name } \\
\text { (initial) }\end{array}$ & Age & Gender & Education & Profession & Marital Status \\
\hline 1 & CT & 25 & F & D3 & Midwife & Married \\
\hline 2 & DY & 30 & F & S1 & Entrepreneur & Married \\
\hline 3 & DW & 33 & F & S1 & Private & Single \\
\hline 4 & RS & 28 & F & S1 & Entrepreneur & Single \\
\hline 5 & MS & 38 & Male & S1 & Entrepreneur & Married \\
\hline 6 & TK & 34 & F & S2 & Private & Married \\
\hline 7 & AA & 30 & Male & S1 & Private & Married \\
\hline 8 & CM & 35 & F & S1 & Entrepreneur & Single \\
\hline
\end{tabular}

Table 1. Identity of Informant

(Source : Result of Research, 2020)

The reason for the millennial generation in West Java having traveling

Based on the interviews conducted, the researchers obtain the results on the reasons for the millennial generation of traveling and tourism lovers in carrying out these activities. CT, 25 years old, a millennial generation who works, but does not want to lose the opportunity to miss traveling in his daily activities.

\section{CT, 25 years old}

"Traveling is a must, if I don't do it, there must be an unbalanced-mood"

DW, 33 years old

"Traveling can make you contemplate nature, enjoy the beauty of the universe, make you so cool, relax every time you have done traveling." 
Tourism and Sustainable Development Review Journal (TSDR), Vol. 1 (1), 25-32

Self-Identity of Millennial Generation as Traveling and Tourism Lovers Case Study Concerning

Demographic And Psychographic Map Of Tourism Communication

Jenny Ratna Suminar, Ditha Prasanti, Moch. Armien Syifaa Sutarjo

DY, 30 years old

"Traveling makes our mind calm; that's why I choose to travel to cool places."

RS, 28 years old

"Traveling becomes a routine for me, and it can't be missed ..."

Based on the explanation above, the researchers see the main reason that causes the informant to travel. Even though it turns out that there are also informants who consider traveling just to make the mind calm. However, more than that, researchers see the millennial generation of traveling lovers making this a mandatory point that must be scheduled as a routine in their activities. According to DW and CT, traveling is like a mood balance, which must be done. It is an interesting finding because researchers see that consciously, in the phenomenological method, the informant revealed his experience of traveling is to get a mood balance in his life. It indicates how crucial traveling activity is for millennials.

The motivation of traveling lovers' hobbies in traveling and travel

Most of the informants say that the primary motivation for traveling is because they want to get mental relaxation from their daily routines. Nevertheless, the researchers find that CT and DY informants have unique motivations. According to him, traveling can make them add gratitude to God. It is interesting for the researchers because, among the other informants, the two informants answer that traveling makes them even more grateful to God.

When it is viewed from the symbolic interaction theory expressed by George Herbert Mead, conceptually, humans have the possibility of their actions and thoughts, which before he starts the actual action, of course, through various considerations. That is what causes human actions to have a closed mental process that precedes the actual process of action (Ritzer, George \& Goodman, 2011).

In this study, the researchers look at the actions of informants in carrying out traveling activities, of course, through various considerations, where it is also related to the main reason for informants to travel. The findings of this study are also following the assumption of symbolic interaction theory that symbols or signs given by humans in conducting interactions have particular meanings.

According to Mead, new communication occurs when each individual not only gives meaning to their behavior but also reaches the level of understanding or trying to understand the meaning given by other parties (Ritzer, George \& Goodman, 2011). Therefore, Blumer introduces the premise of symbolic interactionism as follows:

- Humans perform actions "something" based on the meaning of "something" or known as the mind. When the informant does the traveling activity, this is a symbol that indicates the informant as the millennial generation of traveling lovers has the main reason to enjoy more than just his hobby.

- The meaning of "something" is derived from the social interaction between somebody with one another person, which is known as self when the informant interprets traveling 
for himself more than just relaxation or a compulsory routine. The informant also has its meaning that traveling is a mood balance in his life.

- The meanings handled are modified through an interpretative process used by people in interacting, or known as the concept of society. It is seen in the interaction of the informants when it is known as the millennial generation of traveling lovers. There is a process of interpretation that arises from the communicant or other people in the interaction.

Traveling activities favored by millennials

In this study, the researchers can also find out about the demographic and psychographic maps of the millennial generation in traveling and tourism activities, where this data will be the basis for business people traveling and tourism for a great and profitable business. The five informants in this study mention that they are interested in traveling to new attractions and are becoming a trend at that time.

"The main thing is, I am traveling to a new tourist attraction, a new location that is a more trendy, mainly natural attraction, so it is a mandatory destination to visit on the next traveling schedule". (DW, January 2020)

The informant's statement above explains the existence of traveling activities carried out by the informant to visit locations that are becoming a trend at that time so that the main finding is an opportunity for business travelers to see this opportunity. The following is the table that illustrates the traveling activities of millennial generation along with their motivation and tourist destination information.

\begin{tabular}{|c|c|c|c|c|c|}
\hline No & Name & Motivation & With & Destination & Destination Info \\
\hline 1 & MS & $\begin{array}{l}\text { The demand for work } \\
\text { as an architect which } \\
\text { needs both domestic } \\
\text { and foreign insights; } \\
\text { invite children to open } \\
\text { their insight; } \\
\text { refreshing after a quite } \\
\text { tiring work; enjoy life; } \\
\text { there is a promo }\end{array}$ & $\begin{array}{l}\text { Family } \\
\text { (wife and } \\
\text { children); } \\
\text { some time } \\
\text { with friends }\end{array}$ & $\begin{array}{l}\text { Domestic and foreign; } \\
\text { it can be mountains and } \\
\text { special places }\end{array}$ & $\begin{array}{l}\text { Travel fair } \\
\text { friend; family }\end{array}$ \\
\hline 2 & TK & $\begin{array}{l}\text { Find a new } \\
\text { atmosphere, while } \\
\text { there are no children; } \\
\text { the balance; new food; } \\
\text { There is a ticket promo }\end{array}$ & $\begin{array}{l}\text { Spouse; } \\
\text { friends }\end{array}$ & $\begin{array}{l}\text { Frequently in the } \\
\text { country, although I } \\
\text { certainly plan to go to } \\
\text { several places abroad; } \\
\text { the beach is a favorite } \\
\text { and special place }\end{array}$ & $\begin{array}{l}\text { Social } \\
\text { friend }\end{array}$ \\
\hline 3 & AA & $\begin{array}{l}\text { Encourage children to } \\
\text { broaden the insight; } \\
\text { the need for } \\
\text { refreshing; }\end{array}$ & $\begin{array}{l}\text { Wife and } \\
\text { child }\end{array}$ & $\begin{array}{l}\text { Domestic and foreign } \\
\text { which can be beaches, } \\
\text { mountains, and historic } \\
\text { places }\end{array}$ & $\begin{array}{l}\text { Social media; } \\
\text { travel fair; }\end{array}$ \\
\hline
\end{tabular}


Tourism and Sustainable Development Review Journal (TSDR), Vol. 1 (1), 25-32

Self-Identity of Millennial Generation as Traveling and Tourism Lovers Case Study Concerning

Demographic And Psychographic Map Of Tourism Communication

Jenny Ratna Suminar, Ditha Prasanti, Moch. Armien Syifaa Sutarjo

\begin{tabular}{|l|l|l|l|l|l|}
\hline & & & & & \\
\hline 4 & CM & $\begin{array}{l}\text { Hobby; enjoy life; } \\
\text { there is a promo offer }\end{array}$ & $\begin{array}{l}\text { Friend, } \\
\text { alone } \\
\text { okay }\end{array}$ & $\begin{array}{l}\text { If it is traveling abroad, } \\
\text { I prefer places that have } \\
\text { significance, whether } \\
\text { it's history, etc. }\end{array}$ & $\begin{array}{l}\text { Travel fair; TV; } \\
\text { family; Social } \\
\text { media }\end{array}$ \\
\hline
\end{tabular}

Table 2. Millennial Generation's Traveling Activities

(Source: Research Results, 2020)

The four key informants go for traveling at least one time in a year. They have traveled to both domestic and foreign places. The costs incurred are not small, especially when they travel abroad. But two of the four informants also said that "traveling does not mean forgetting future planning, especially for children. Children's health and education costs are the priority. But traveling is good for balance and motivation to make a lot of money".

The findings of this study also enrich the previous literature studies that mention millennial generation consisting of productive workforce groups, attach great importance to Work-LifeBalance. The researchers see the informant's statement that mentions mood balance as the main reason for traveling. The millennial generation, in this case, also likes something that becomes a trend, a great curiosity drives him to visit tourist sites that are a trend at that time.

Schwitzer et.all (2010) reveals that this millennial generation prioritizes a balance between the world of work and personal life than the previous generation. They tend to choose jobs that are more flexible in terms of conditions and working hours so that they can have more free time with friends, family, or to develop a hobby, as the results of the research they do (Ng, ES, Schweitzer, L., \& Lyons, 2010). Other findings that support the demographic and psychographic maps of the millennial generation of traveling lovers are that they would rather spend money on specific experiences than save money to add assets. Of course, millennials generally prefer to travel around Indonesia and the world rather than saving for investment.

\section{CONCLUSION}

Millennials between the ages of 23-38 are known as a generation that likes traveling rather than investing in funds, and this is the focus of the research. The result of the research shows that:

- The motivation of millennials to go traveling is: a) the demand of work; b) refreshing after working hard; c) introducing insight to children; d) getting life balance; e) enjoying life; f) hobbies; g) getting something new including special food

- Millennials go for traveling with: a) family, friends, and solo; b) while the traveling destinations can be domestic or foreign where they include beaches, mountains or special places; c) information about the destination is obtained from friends, social media, TV, or from the travel fair

- Traveling makes the savings reduced enough, but it is very fun and makes work motivation to get a lot of money. Millennial believes that by liking traveling does not mean forgetting future planning, funding for education, and children's health remains a priority. 
From the results of this study, there is a recommendation that becomes important notes for business travelers, that according to the data, the millennial generation is the population that mostly dominates in Java. Business traveling and tourism both for domestic and foreign, has a very good and promising target. Furthermore, millennials and parents to continue to provide reinforcement regarding the sustainability of life to give priority to what is important because life is not just a pleasure for traveling.

\section{REFERENCES}

Creswell, J. W. (2012). RESEARCH DESIGN Pendekatan Kualitatif, Kuantitatif, dan Mixed. Yogyakarta: Pustaka Pelajar.

Croitoru, A. G. (2017). INNOVATION IN TECHNOLOGY-HOW TRAVEL BECOMES "SMART “. CLEANER PRODUCTION AND GREEN ECONOMY, 160.

Garnesia, I. (2018). Sana-sini Ngaku Milenial, Bagaimana Peta Milenial Indonesia? Retrieved from Tirto.Id website: Baca selengkapnya di artikel \%22Sana-sini Ngaku Milenial, Bagaimana Peta Milenial Indonesia?\%22, https://tirto.id/cX5W

Madara, S. R., Maheshwari, P., \& Selvan, C. P. (2018). Future of millennial generations: A review. In 2018 Advances in Science and Engineering Technology International Conferences (ASET) (Pp. 14). IEEE., $1-4$.

Ng, E. S., Schweitzer, L., \& Lyons, S. T. (2010). New generation, great expectations: A field study of the millennial generation. Journal of Business and Psychology, 25(2), 281-292, 25(2), 281-292.

Rita, P., Brochado, A., \& Dimova, L. (2019). Millennials' travel motivations and desired activities within destinations: A comparative study of the US and the UK. Current Issues in Tourism, 22(16), 2034-2050., 22(16).

Ritzer, George \& Goodman, D. J. (2011). Teori Sosiologi Modern. Jakarta: PT Kencana. 